\title{
Potential of Kazakhstan's grain export trade
}

\author{
Yameng Wang ${ }^{1}$ (D) Peipei Huang ${ }^{1}$ (D) Zaid Ashiq Khan ${ }^{1}$ (D) Feng Wei ${ }^{1^{*}}$ (D)
}

${ }^{1}$ College of Economics and Management, Northwest Agriculture and Forestry University, 712100, Yangling, China. E-mail: Weifeng@nwsuaf.edu.cn. ${ }^{*}$ Corresponding author.

\begin{abstract}
Kazakhstan is located in the hinterland of Central Asia. Its virtuous geographical advantages and huge grain production potential make it one of the most important grain exporters in the world. The research on the problem of the grain trade in Kazakhstan is of great significance for food security. This study measured its international competitiveness using the International Market Share Index, the Revealed Comparative Advantage Index, Trade competitiveness index and calculated the international competitiveness and analyzed the influencing factors of grain export by constructing an extended gravity model and measured its export potential. Results showed that Kazakhstan has a low share of the international grain market; however, wheat, barley, and buckwheat have strong export advantages; the level of economic development and economic distance has significantly promoted the scale of grain exports. While geographical distance, the difference in GDP per capita, and the fact whether trading partner countries have joined the Eurasian Economic Union have caused obstacles to grain exports. Kazakhstan's export potential to 6 countries including Russia, Kyrgyzstan and China shows an upward" trend, its export potential to 6 countries including Tajikistan and Ukraine showing a "stable" trend, and its export to 9 countries included Poland and Germany. The potential showed a "declining" trend.
\end{abstract}

Key words: grain, potential for trade, international competitiveness, Kazakhstan.

O potencial do comércio de exportação de grãos do Cazaquistão

RESUMO: O Cazaquistão está localizado no interior da Ásia Central. Suas virtuosas vantagens geográficas e grande potencial de produção de grãos a tornam um dos exportadores de grãos mais importantes do mundo. A pesquisa sobre o problema do comércio de grãos no Cazaquistão é de grande importância para a segurança alimentar. Este estudo mede sua competitividade internacional por meio do indice $I M S$, índice RCA, índice TC e calcula a competitividade internacional e analisa os fatores influenciadores da exportação de grãos por meio da construção de um modelo gravimétrico estendido e mede seu potencial exportador. Os resultados mostram que o Cazaquistão tem uma baixa participação no mercado internacional de grãos; no entanto, trigo, cevada e trigo sarraceno têm fortes vantagens de exportação; o nível de desenvolvimento econômico e a distância econômica têm promovido significativamente a escala das exportações de grãos. Embora a distância geográfica, a diferença no PIB per capita e o fato de os países parceiros comerciais terem aderido à União Econômica da Eurásia têm causado obstáculos às exportações de grãos. O potencial de exportação do Cazaquistão para seis países, incluindo Rússia, Quirguistão e China mostra uma tendência de "alta", seu potencial de exportação para seis países, incluindo Tajiquistão e Ucrânia, mostra uma tendência " estável "e sua exportação para nove países, incluindo Polônia e Alemanha. O potencial mostra uma tendência de "declínio".

Palavras-chave: grãos, potencial comercial, competitividade internacional, Cazaquistão.

\section{INTRODUCTION}

Grain import and export trade is an important means to regulate the global food supplydemand imbalancing and maintaining national food security. The trade of grain and other agricultural products has become more and more important as a way to adjust resources between countries with abundant resources and countries with scarce resources (QIANG et al., 2013). International food prices have fluctuated sharply affected by factors such as novel coronavirus pneumonia (COVID-19), the tight relation of global food production and demand, macroeconomic, and geopolitical changes in recent years. The prices of major grains such as corn, soybeans, and wheat have risen and fallen sharply, which had a greater impact on ensuring national food security.

Kazakhstan, located in the hinterland of Central Asia, is the world's largest food producer and exporter. According to FAO, Kazakhstan's total grain output in 2018 was 20.04 million tons, ranking 28th in the world; total grain export was 8.53 million tons, ranking 13th in the world. The "2019 Global Food 
Security Index Report" shows that Kazakhstan's food security level ranks 48th among 113 countries in the world, while in 2018 it was ranked as 58th (The Economist-Intelligence Unit, 2019). In recent years, Kazakhstan's grain export trade has developed promptly and turn out to be an important potency in the international grain market. According to UN Comtrade Database, Kazakhstan's total grain export volume reached 1.304 billion USD in 2018, with an increase of $57.59 \%$ over 2017. Among them, wheat was the most important grain export product, with an export value of 972 million USD, accounting for $74.54 \%$ of Kazakhstan's total food export; the export value of barley was 294 million USD, accounting for $22.55 \%$; the export value of rice was 26 million USD, accounting for $2.01 \%$. The export volume of these three major categories of grain crop products accounted for $99.1 \%$. In terms of time series (Figure 1), the total export value of wheat during 2008-2018 fluctuated dramatically, dropping from 1.459 billion USD in 2008 to 972 million USD in 2018, reaching the highest in 2012. Barley export was on a steady growth trend, increasing from 157 million USD in 2008 to 294 million USD in 2018. The export value of rice remained unchanged basically, less than 400 million USD throughout the time.

From the perspective of spatial pattern, the grain export market presented the regionally concentrated geographic patterns of "central Asia as the main area, radiating all around". Meanwhile, Uzbekistan, Tajikistan, China, and Iran occupied the position of important trading partners. In 2018, the main destinations of Kazakhstan's wheat exports were Uzbekistan, Tajikistan, China, Italy, Afghanistan, and Turkey, which accounted for $73.59 \%$ of Kazakhstan's total wheat export volume together. The main export market for the barley was concentrated in Iran, and a small part was exported to Russia, Germany, the United Kingdom, and other western developed countries. In 2018, Kazakhstan exported 272.4 million USD of barley to Iran, accounting for $92.80 \% ; 120$ million USD of barley was exported to Uzbekistan, accounting for 4.08\%; Asian countries accounted for $99.49 \%$ of Kazakhstan's total barley export volume together (Figure 2).

Good geographical advantages and huge grain production potential make Kazakhstan one of the most important grain exporters in the world. It is considered by the Food and Agriculture Organization of the United Nations and the European Bank for Reconstruction and Development to be one of the only four countries in the world whose food production capacity is underutilized and can have a significant impact on meeting global food demand. However, an adjustment in agricultural policy as a result of changes in the market system has led to a significant decrease in the total amount of agricultural

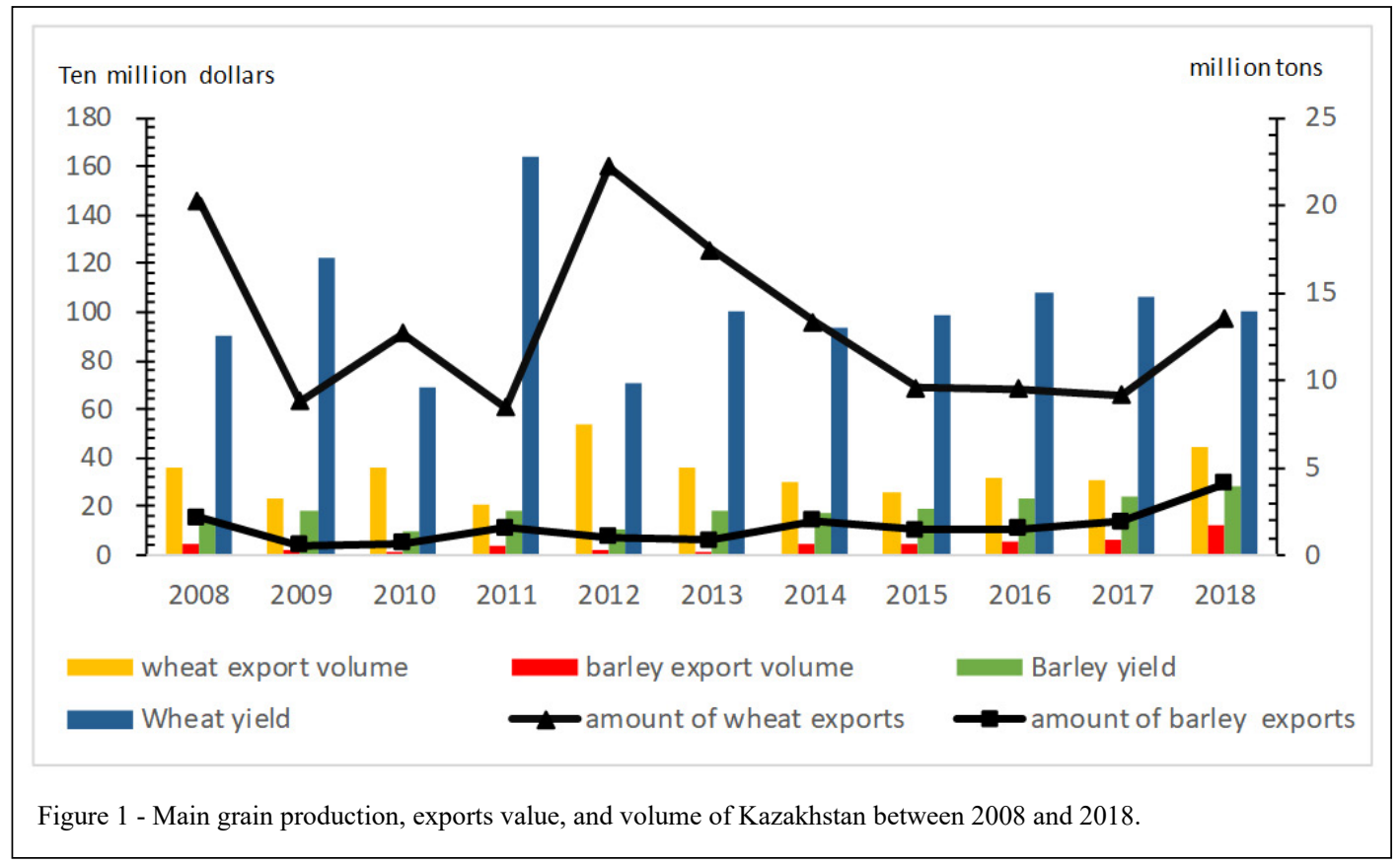

Ciência Rural, v.52, n.1, 2022. 


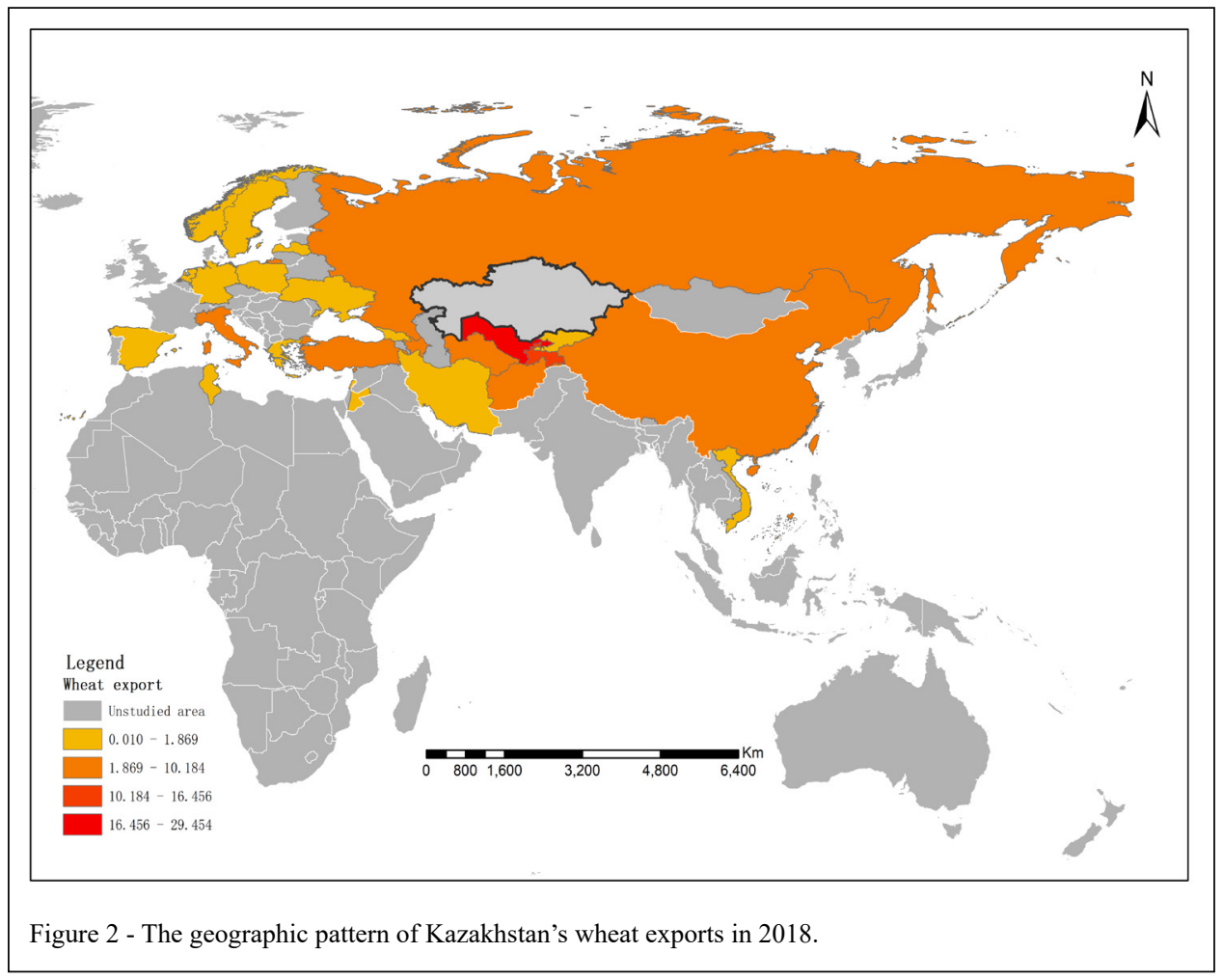

land used in Kazakhstan, with a $35 \%$ reduction in the area of arable land since independence in 1992 (SWINNEN \& VAN HERCK, 2011). The decrease in the area of arable land, instability of grain trade development, the extensive growth of grain trade, and the low contribution to the development of agricultural industry affect the optimization of grain trade structure and the development of grain trade potential in Kazakhstan (KHAN et al., 2017). At the same time, the high inland transportation cost also led to a relatively single market for grain exports, which weakened Kazakhstan's competitiveness in international trade.

The research on Kazakhstan's grain mainly includes three areas: grain production, grain trade, and food security. In the field of grain production, existing studies focused on the current situation, production potential, and influencing factors of food production in Kazakhstan. As the largest grainproducing country in Central Asia, Kazakhstan has abundant cultivated land resources (XIN et al., 2019). However, due to the limited level of agricultural modernization, crop growth is highly dependent on the weather, leading to large fluctuations in grain production (PAVLOVA et al., 2014). At the same time, factors such as agricultural policies, damaged infrastructure, insufficient storage capacity, and the use of fertilizers have also had a significant impact on Kazakhstan's grain production (ZAVALIN et al., 2018). It is estimated that the maximum potential area of wheat harvest in Kazakhstan is 190,000 ha, the maximum yield potential is 1.6 tons per hectare and the total amount is 29 million tons (ZHU, 2014). Kazakhstan will be able to further improve the natural disaster resistance for grain production and the efficient utilization of natural resources (CAO et al., 2011).

In terms of grain trade, except for the reduction of grain crop production in 2010, it generally showed an increasing trend in other years. Based on meeting domestic food demand, Kazakhstan has considerable export potential (ZHANAKOVA et al., 2015). In addition, factors such as food supply capacity, per capita income difference, labor force quantity, trade facilitation degree, foreign trade policy, and storage-logistics facility have also affected the expansion of grain trade in Kazakhstan to a certain extent (GRAFE et al., 2008). China is Kazakhstan's largest trading partner, and agricultural cooperation between the 
two countries also shows great development potential (RABALLAND \& ANDRESY, 2007). However, the current China-Kazakhstan grain trade is small, and the trade varieties are particular due to factors such as the unstable agricultural production, insufficient grain storage, logistics capacity, low trade convenience, and the long-distance from the grain-producing area to China's import area. The current total trade volume of major agricultural products between China and Kazakhstan is relatively small and the categories of agricultural products cross each other in which the two countries have comparative advantages in export. The complementarity between China's exports and Kazakhstan's imports is strong and on the rise as a whole, while the complementarity between Kazakhstan's exports and China's imports are low. The two countries have great potential for bilateral trade growth (LING WANG, 2015).

In terms of food security, most of the existing studies have expounded on the impact of Kazakhstan's national food policy on the food security of the country and the world, from the perspectives of agricultural policy reform and temporary export restriction policies. At the current stage, Kazakhstan grain can be self-satisfied and can be exported for foreign exchange, so there is less pressure on food security. The main tasks of the Kazakh government are to improve the planting structure, increase production, maintain food price stability, and reduce inflation pressure for national food security (BAYDILDINA A et al., 2000).

The above research analyzed the problems of Kazakhstan's grain production and trade from different perspectives, which provided a solid theoretical basis and practical reference for the study of this paper, but there are still some deficiencies. Based on the abovementioned research gaps, this article contributes to the field in two ways. Firstly, taking the temporal and spatial pattern of grain export trade in Kazakhstan as the starting point, through the calculation of the international market share, export advantage, and trade competitiveness of different grain crops, we can accurately grasp the current export situation and international competitiveness of all kinds of grain products in Kazakhstan, and provide basic data support for grain trade cooperation between Kazakhstan and other countries in the world. Secondly, by using the gravity model to calculate the potential and changing trend of Kazakhstan's grain export trade, it can help us to find out the main reasons that affect the export potential and provide corresponding recommendations.

\section{MATERIALS AND METHODS}

\section{International competitiveness model}

The international competitiveness of grain exports not only reflects the production and export capacity of Kazakhstan's grain but also an important indicator to measure its viability and trade status in the international market. Existing researches mainly use the International Market Share Index (IMS), the Revealed Comparative Advantage Index (RCA), and the Trade Competition Index (TC) to measure the international competitiveness of a certain product in a sustainable period of time.

\section{International market share index (IMS)}

IMS reflects changes in international competitiveness and the competitive position of a country's certain industry or product. The calculation formula is:

$I M S_{i j}=\frac{X_{i j}}{X_{w j}}$

$\mathrm{IMS}_{\mathrm{ij}}$ indicates the International Market Share Index, is the $X_{i j}$ total exports value of product $j$ in country $i$, $\mathrm{X}_{\mathrm{wi}}$ is the total export value of product $\mathrm{j}$ in the world. When $\mathrm{IMS}_{\mathrm{ij}}>20 \%$, the international competitiveness of product $\mathrm{j}$ in the country $\mathrm{i}$ is very strong; when $10 \%<\mathrm{IMS}_{\mathrm{ij}}<20 \%$, it is relatively strong; when $5 \%<\mathrm{IMS}_{\mathrm{ij}}<10 \%$, it is general; when $\mathrm{IMS}_{\mathrm{ij}}<5 \%$, it is weak.

\section{Revealed comparative advantage index (RCA)}

$\mathrm{RCA}$ reflects the advantage degree of different products in a country's foreign trade. The product with higher indices has better export advantages, its calculation formula is:

$R C A_{i j}=\frac{X_{i j} / X_{i}}{X_{w j} / X_{w}}$

$\mathrm{RCA}_{\mathrm{ij}}$ indicates the Revealed Comparative Advantage Index, $\mathrm{Xij}$ is the total exports value of product $\mathrm{j}$ in country $\mathrm{i}, \mathrm{X}_{\mathrm{i}}$ is the total export value of country $i$ to the world, $X_{w j}$ is the total export value of product $\mathrm{j}$ in the world, $\mathrm{X}_{\mathrm{w}}$ is the world's total export value. When $\mathrm{RCA}_{\mathrm{ij}}>2.5$, the export advantage of product $\mathrm{j}$ in-country is extremely strong; when $1.25<\mathrm{RCA}_{\mathrm{ij}}<2.5$, the export advantage is very strong; when $0.8<\mathrm{RCA}_{\mathrm{ij}}<1.25$, it is relatively strong; when $\mathrm{RCA}_{\mathrm{ij}}<0.8$, it is weak.

\section{Trade competitiveness index (TC)}

TC is a powerful tool to measure the international competitiveness of a certain product in a country. Its calculation formula is: 
$T C_{i j}=\frac{X_{i j}-M_{i j}}{X_{i j}+M_{i j}}$

$\mathrm{TC}_{\mathrm{ij}}$ indicates the Trade Competition Index, $\mathrm{X}_{\mathrm{ij}}$ is the total export value of product $\mathrm{j}$ in country $\mathrm{i}, \mathrm{M}_{\mathrm{i}}$ is the total import value of product $j$ in the country $i$. When $\mathrm{TC}_{\mathrm{ij}}>0$, it means that the production efficiency of product $\mathrm{j}$ in the country $\mathrm{i}$ is higher than the international level and has strong international competitiveness. When $\mathrm{TC}_{\mathrm{ij}}=0$, it means that the production efficiency of product $j$ in the country $i$ is equivalent to the international level, and its import and export are purely international exchanges of varieties. The value range of TC is from -1 to 1 , among them, the higher TC value represents the stronger international competitiveness; otherwise, it indicates that a certain product or industry does not possess or lack international competitiveness.

\section{Gravity model}

The gravity model is one of the methods used to measure trade potential commonly, which takes influence factors of trade potential as explanatory variables, trade volume as an explained variable. This method uses regression analysis to determine the significant influence factors and the effective weight of each factor on the trade volume, then calculates the trade potential. The basic gravity model is:

$Y_{i j}=a\left(G D P_{i} G D P_{j}\right) /$ Distance $_{i j}$

$\mathrm{Y}_{\mathrm{ij}}$ represents the total trade volume of exporting country $\mathrm{i}$ to importing country $\mathrm{j}$, GDP represents the economic aggregate of country $i$, GDP represents the economic aggregate of country $\mathrm{j}$, Distanceij represents the geographical distance between two countries, $\mathrm{A}$ is the regression parameter.

This paper uses the research of Aigner to construct a model of Kazakhstan's grain export potential with random error (AIGNER et al., 1977). This paper selects dummy variables such as economic development, population size, geographical and economic distances from Kazakhstan and its major grain trading partners to be explanatory variables, to study the influence of various factors on Kazakhstan's grain export trade flow. In order to avoid the heteroscedasticity and non-normality of data residuals, the logarithmic gravity model is generally used in practical research. The estimated equation of the extended gravity model is:

$\ln Y_{i j t}=\beta_{0}+\beta_{1} \ln \left(G D P_{i t} G D P_{j t}\right)+\beta_{2} \ln \left(P O P_{i t} P O P_{j t}\right)+\beta_{3} \ln \left(G p c g_{i j t}\right)$

$+\beta_{4} \ln \left(D i s_{i}\right)+\beta_{5} \ln \left(E F_{j t}\right)+\beta_{6} \ln \left(E D_{j t}\right)+\beta_{7} \ln \left(P D_{j t}\right)+\beta_{8} \ln \left(\right.$ Lang $\left._{j}\right)$

$+\beta_{9}$ Bord $_{j}+\beta_{10}$ Land $_{j}+\beta_{11}$ WTO $_{j}+\beta_{12}$ CIS $_{j}+\beta_{13} E E U_{j}+v_{i j t}$

In the equation, i represents Kazakhstan, j represents Kazakhstan's grain trading partner, t represents the year, $Y_{\mathrm{ijt}}$ represents Kazakhstan's grain export trade value to importing country $\mathrm{j}$, $\mathrm{v}_{\mathrm{ijt}}$ represents the random disturbance term in the model. The detailed table is listed to further explain the meaning of each explanatory variable, expected influence direction, and related brief theory (Table 1).

The applicability of the gravity model to study grain trade potential is mainly reflected in the following aspects: (1) Grain export is affected by factors such as the production capacity and product quality in the export country, the economic development and population size in the importing country, and the distance between the two countries, reflecting a gravity relationship; (2) To obtain the predicted value, Kazakhstan's grain export potential needs to be calculated by gravity model; (3) The gravity model has a good explanatory ability in studying bilateral trade issues, and its data acquisition is simpler than other commonly used models.

\section{Data source and sample description}

This research selected the data of Kazakhstan and its 21 major grain trading partners from 2008 to 2018, with the list of countries in figure 3 . The data was taken from the FAOSTAT, UN Comtrade Database, World Bank database, the Heritage Foundation, World Bank's Global Governance indicators, CEPII database. The classification of grain and its products is selected according to categories 10, 11, and 19 in the International Convention for Harmonized Commodity Description and Coding System of 1992 edition (HS92) in table 2.

\section{RESULTS}

\section{Kazakhstan's grain international competitiveness}

From the overall trend, the international competitiveness of Kazakhstan's grain had gradually increased from general, and finally stabilized within the range of relatively strong $(10 \%<$ IMS $<20 \%$ ) (Figure 4 ). Wheat and barley were the most competitive grain crops, with their average annual IMS of $2.3 \%$ and $1.6 \%$ from 2008 to 2018 respectively; rye, corn, and rice had weak competitiveness in the international market, with their IMS below $0.2 \%$ throughout. The IMS of wheat, buckwheat, and barley fluctuated sharply. Among the common grain crops in Kazakhstan, the IMS of wheat, buckwheat, and barley fluctuated sharply during 2008-2018, while the IMS of the others maintained stable.

According to the TC of grain export (Figure 5), among the 8-grain crops, wheat, barley, oats, and millet had a strong international competitive 
Table 1 - Meaning and theoretical description of each variable of the gravity model.

\begin{tabular}{|c|c|c|c|}
\hline Variable & Meaning & Expected & Theoretical Explanation \\
\hline$Y_{i t} Y_{j t}$ & $\begin{array}{l}\text { The real economy of } \\
\text { Kazakhstan and country } \mathrm{j}\end{array}$ & + & $\begin{array}{l}\text { The level of economic development of both trading parties is positively } \\
\text { related to bilateral trade flows }\end{array}$ \\
\hline$A_{i t} A_{j t}$ & $\begin{array}{l}\text { The total population of } \\
\text { Kazakhstan and country } \mathrm{j}\end{array}$ & + & $\begin{array}{l}\text { The larger the population, the greater the demand for food, which will } \\
\text { promote food trade }\end{array}$ \\
\hline$B_{i f t}$ & $\begin{array}{l}\text { The absolute value of per } \\
\text { capita GDP gap between } \\
\text { country j and Kazakhstan } \\
\text { in year t }\end{array}$ & - & $\begin{array}{l}\text { According to Linde's demand similarity theory, the smaller the per capita } \\
\text { GDP gap, the smaller the resistance of traded products to enter the } \\
\text { countries of the two countries, and the smaller the international trade cost } \\
\text { relative to the domestic trade cost, the greater the bilateral trade flow } \\
\text { between the two countries. }\end{array}$ \\
\hline$D_{i}$ & Geographic distance & & $\begin{array}{l}\text { The greater the geographical distance between the two countries, the } \\
\text { higher the cost and difficulty of the food trade. }\end{array}$ \\
\hline$E_{j t}$ & $\begin{array}{l}\text { The level of economic } \\
\text { freedom of country } \mathrm{j}\end{array}$ & + & $\begin{array}{l}\text { The higher the level of economic freedom of Kazakhstan's food trading } \\
\text { partner countries, the lower the "hidden cost" of trade between the two } \\
\text { parties }\end{array}$ \\
\hline$F_{j t}$ & $\begin{array}{l}\text { Economic distance } \\
\text { between trading partner } \\
\text { countries and Kazakhstan }\end{array}$ & - & $\begin{array}{c}\text { Economic distance is a measure of quantifiable policy costs, taxes, and } \\
\text { investment, and financial freedom that are difficult to quantify between } \\
\text { countries. The longer the economic distance, the greater the resistance to } \\
\text { bilateral grain trade. }\end{array}$ \\
\hline$G_{j t}$ & $\begin{array}{l}\text { Political distance between } \\
\text { trading partner countries } \\
\text { and Kazakhstan }\end{array}$ & - & $\begin{array}{l}\text { Political distance refers to the influence of the political environment, } \\
\text { political system, and power structure of the trading parties when } \\
\text { conducting economic activities. The farther the political distance is, the } \\
\text { greater the resistance to bilateral food trade is. }\end{array}$ \\
\hline$H_{j}$ & $\begin{array}{l}\text { Language similarity } \\
\text { between country } \mathrm{J} \text { and } \\
\text { Kazakhstan }\end{array}$ & + & $\begin{array}{l}\text { Identical or similar cultures will increase the scale of bilateral trade and } \\
\text { promote grain import and export trade }\end{array}$ \\
\hline$L_{j}$ & common boundary & + & $\begin{array}{l}\text { Bordering with Kazakhstan can effectively reduce various costs in the } \\
\text { food transportation process and promote the development of food trade }\end{array}$ \\
\hline$M_{j}$ & Landlocked country & - & $\begin{array}{l}\text { The import and export of bulk grain in landlocked countries can only be } \\
\text { limited to rail transport, which is more expensive than water transport }\end{array}$ \\
\hline$N_{j}$ & Join the WTO & + & $\begin{array}{l}\text { Joining the WTO is conducive to improving the trading environment, } \\
\text { attracting foreign investment, and bringing greater development markets } \\
\text { and opportunities for food trade in various countries }\end{array}$ \\
\hline$O_{j}$ & CIS countries & + & $\begin{array}{l}\text { Kazakhstan is a CIS country. If its food export partners are also CIS } \\
\text { countries, there is less resistance to bilateral food trade. }\end{array}$ \\
\hline$P_{j}$ & $\begin{array}{l}\text { Eurasian Economic } \\
\text { Union }\end{array}$ & + & $\begin{array}{l}\text { The Eurasian Economic Union is a supranational alliance planned to } \\
\text { deepen economic and political cooperation and integration. If Kazakhstan } \\
\text { is a member of the Eurasian Economic Union, bilateral trade resistance } \\
\text { will be small. }\end{array}$ \\
\hline
\end{tabular}

advantage; while the TC of the other grain crops fluctuated constantly, and their trade competitiveness was unstable. The TC of wheat was above 0.96 all through; the barley's TC decreased first and then increased, but it was always higher than 0 ; the oats and millet's TC remained around 0.92. These indicated that the domestic productivity of wheat, barley, oats, and millet in Kazakhstan has always been higher than the international level, maintaining net export status, with a strong competitive advantage in international trade; however, the production efficiency of the other grain crops was unstable.

According to the TC of grain export (Figure 6), among the 8-grain crops, wheat, barley, oats, and millet had a strong international competitive advantage; while the TC of the other grain crops fluctuated constantly, and their trade competitiveness was unstable. The TC of wheat was above 0.96 all through; the barley's TC decreased first and then increased, but it was always higher than 0 ; the oats and millet's TC remained around 0.92. These indicated that the domestic productivity of wheat, barley, oats, and millet in Kazakhstan has always been higher than the international level, maintaining net export status, with a strong competitive advantage in international trade; however, the production efficiency of the other grain crops was unstable. 


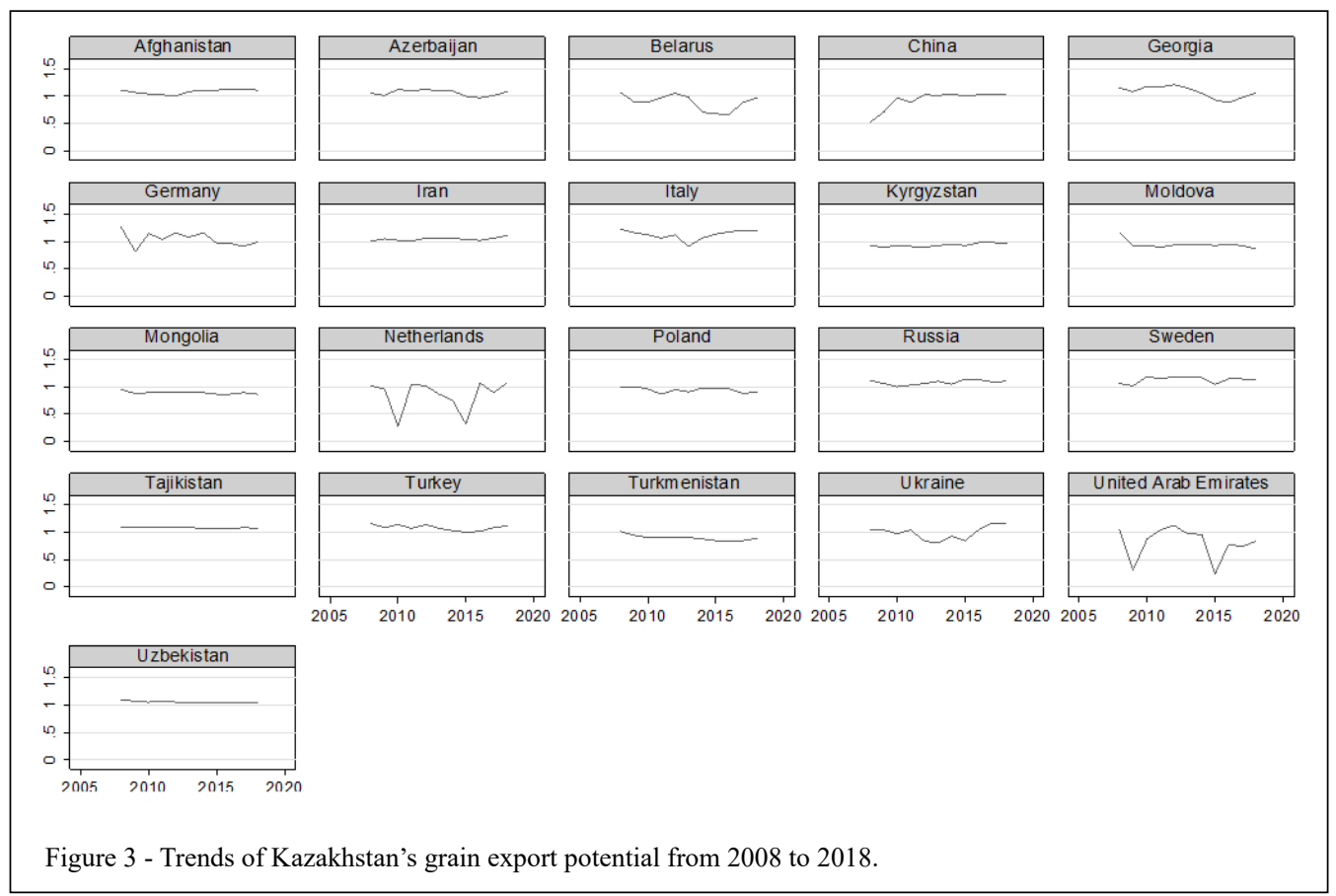

\section{Model regression results and analysis}

In this study, Stata 16.0 software was used to perform statistical tests on the regression equations through mixed regression models, fixed-effects models, or random-effects models. In the test results of the mixed regression model and the fixed effects model, the P-value of the F-test was 0.000 , indicating that the fixed effects model was significantly superior to the mixed regression model, but the F test was not effective without using robust standard error. Hence the test results needed to be further investigated by the LSDV method, where most individual virtual variables were significant $(\mathrm{P}<0.1)$. Therefore, the null hypothesis that "all individual dummy variables are 0" was rejected, and it was considered that the individual effects exist and mixed regression should not be used. Then, the Hausmann test was used to determine whether to establish a random-effects model or a fixed-effects model. The result showed that the p-value was 0.138 , so the null hypothesis and the random effect model were accepted. Considering that the research contained time-invariant variables, and the possibility of heteroscedasticity, serial correlation, and cross-sectional correlation, the

Table 2 - The specific classification of grain and its products.

\begin{tabular}{|c|c|}
\hline Category & Specific Grain Classification \\
\hline $\begin{array}{l}\text { Class } 10 \\
\text { (cereals) }\end{array}$ & $\begin{array}{c}1001 \text { (Wheat and Meslin), } 1002 \text { (Rye), } 1003 \text { (Barley), } 1004 \text { (Oats), } 1005 \text { (Maize), } 1006 \text { (Rice), } 1007 \\
\text { (Grain Sorghum), } 1008 \text { (Buckwheat, Millet, and Canary Seeds) }\end{array}$ \\
\hline $\begin{array}{l}\text { Class } 11 \\
\text { (products of milling industry) }\end{array}$ & $\begin{array}{c}1101 \text { (Wheat or meslin flour), } 1102 \text { (Cereal flours), } 1103 \text { (Cereal groats), } 1104 \text { (Cereal grains otherwise } \\
\text { worked), } 1105 \text { (Flour, meal, powder, flakes, granules, and pellets of potatoes), } 1106 \text { (Flour, meal, and } \\
\text { powder), } 1107 \text { (Malt), } 1108 \text { (Starches), } 1109 \text { (Wheat gluten) }\end{array}$ \\
\hline $\begin{array}{l}\text { Class } 19 \\
\text { (preparations of cereals) }\end{array}$ & $\begin{array}{l}1901 \text { (Malt extract), } 1902 \text { (Pasta), } 1903 \text { (Tapioca and substitutes therefor prepared from starch), } 1904 \\
\text { (Prepared foods obtained by swelling or roasting cereals or cereal products) }\end{array}$ \\
\hline
\end{tabular}

Source: UN Comtrade Database. https://comtrade.un.org/Data.

Ciência Rural, v.52, n.1, 2022. 


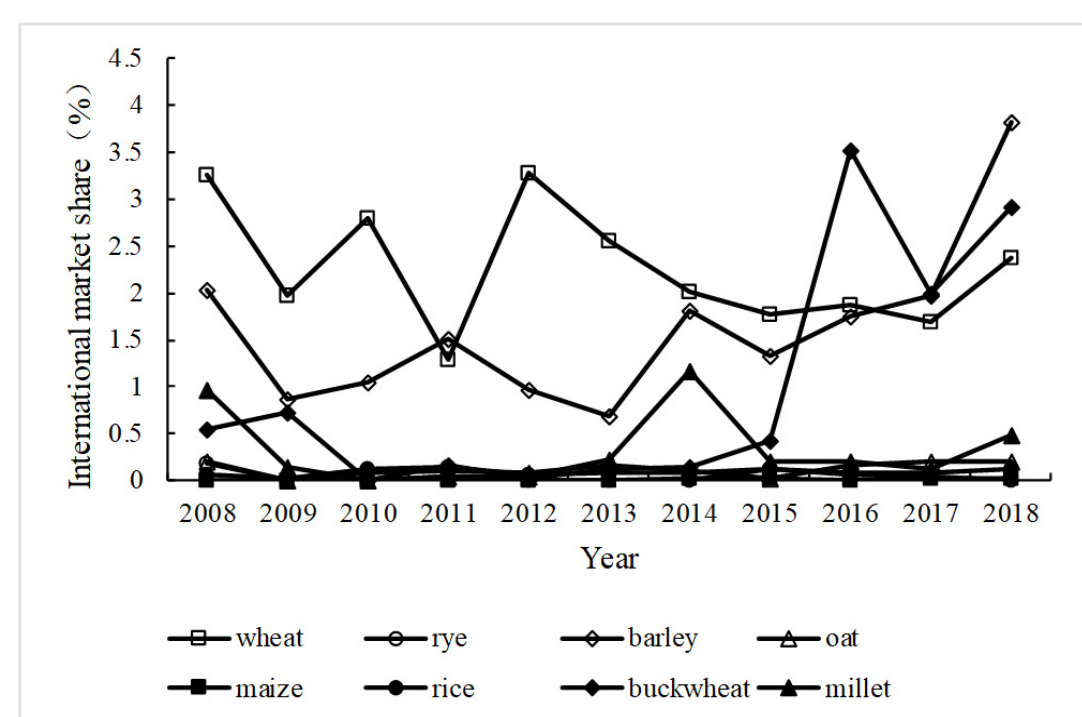

Figure 4 - International market share of Kazakhstan's main grain between 2008 and 2018 (\%).

random effects were selected for estimation, which was suitable for analyzing the panel regression with time-invariant variable (Table 3 ).

It could be seen from the regression results of the random-effects model, that the significance level of $\mathrm{F}$ value was 0.000 , and $\mathrm{R} 2$ was equal to
0.595, indicating that the model had good fitting and reliability. Among the selected variables, the distance of GDP per capita and whether to join the Eurasian Economic Union passed the significance test at $1 \%$ statistical level; the geographic distance in bilateral trade passed the statistical significance test

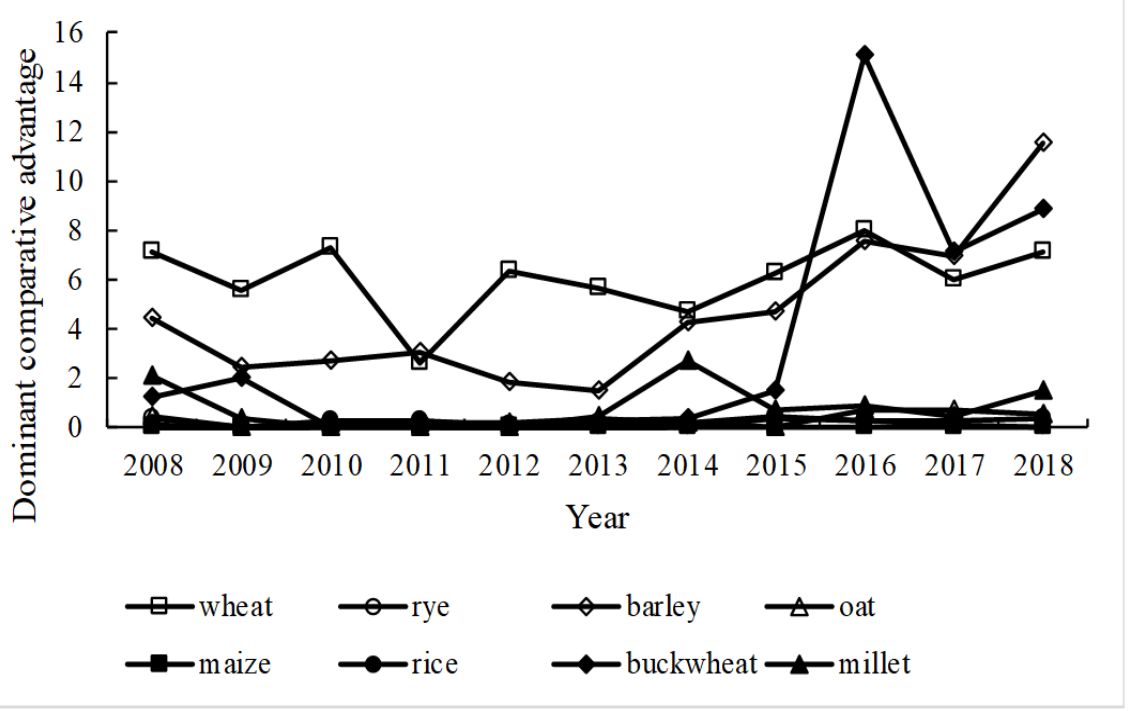

Figure 5 - Dominant comparative advantage index of Kazakhstan's main Grain between 2008 and 2018.

Ciência Rural, v.52, n.1, 2022. 


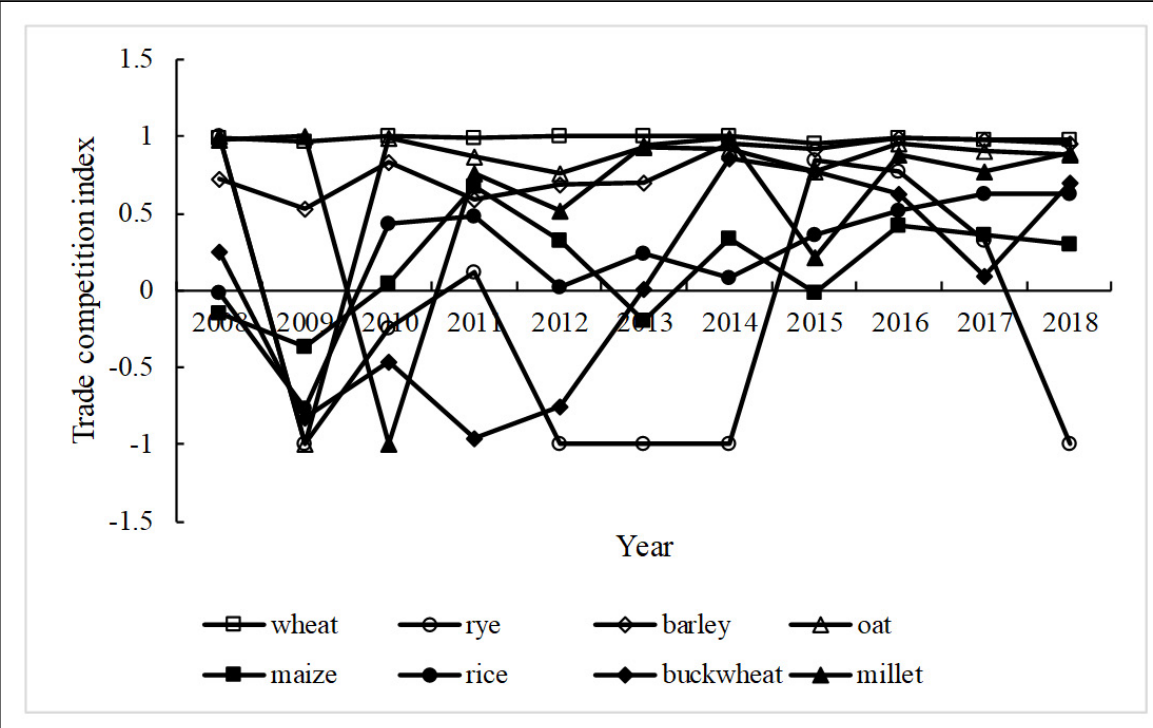

Figure 6 - Trade competition index of Kazakhstan's main Grain between 2008 and 2018.

at $5 \%$ level; the actual economic level and economic distance passed at $10 \%$; the other factors even did not pass at $10 \%$.

The actual economic level of trading countries had a positive impact on grain ex-ports. Economic distance had a positive effect, but the impact was weak. It reflected that factors such as policy costs, taxation, investment freedom, and financial freedom which was difficult to quantify, had little actual resistance to Kazakhstan's grain export trade. The per capita GDP gap harmed grain exports. When the gap was smaller, the residents' living standards in the two trading countries were similar, and the demand preferences were closer, which was more conducive to the expansion of bilateral trade. The geographical distance had a negative impact, which affected the trade cost. The greater the geographical distance, the higher the trade cost, and the more difficult it was for the two countries to develop trade. Whether it had a common border with Kazakhstan, and whether it was a landlocked country did not have a significant impact on grain exports. Because Kazakhstan was located in the center of the Eurasian continent, it had unique conditions to develop transit transport, which weakened the border effect of the bilateral grain trade.

Among these institutional factors, only the variable of whether the trading partner country joined the Eurasian Economic Union (EEU), significantly affected the grain trade between Kazakhstan and its trading partners. After joining the EEU, one country's grain exports would be affected by the grain trade of other countries. If the grain price in other countries decreased, the country would confront intense competition in the international market, which would harm the grain trade exports. Neither the language similarity between the trading partners and Kazakhstan nor the population on both trade sides had a significant impact on the bilateral trade. Food security is related to the country's security and stability, so the national government will adopt appropriate intervention policies to hinder the large-scale grain imports and avoid the dilemma of dependence on food imports. In addition, grain exports are not easily affected by cultural differences in various countries.

\section{Export potential measurement}

First, the theoretical value of Kazakhstan's total grain exports to various countries was calculated based on the regression parameters of the random effect model. Then calculate the ratio of actual value to theoretical value to obtain the potential of the bilateral grain trade. $T P_{t}-T / T_{t}^{*}$

$\mathrm{TP}_{\mathrm{t}}$ is the trade potential index of Kazakhstan during $t$ period, $\mathrm{T}_{t}$ and $\mathrm{T}_{\mathrm{t}}^{*}$ is the actual trade volume and the theoretical trade volume respectively. Referring to Liu and Jiang (.QINGFENG 
Table 3 - Comparison of panel data regression estimation results based on the gravity model.

\begin{tabular}{|c|c|c|c|}
\hline Variable & Mixed OLS & Fixed effect & Random effect \\
\hline & coefficient（p value） & coefficient ( $p$ value $)$ & coefficient ( $p$ value) \\
\hline In $\left(G D P_{i t} G D P_{j t}\right)$ & $1.151^{* * *}(0.002)$ & $2.216(0.120)$ & $0.983^{*}(0.071)$ \\
\hline In $\left(P O P_{i t} P O P_{j t}\right)$ & $-0.971^{* *}(0.016)$ & $-6.016(0.207)$ & $-1.005(0.129)$ \\
\hline In $\left(G p c g_{i j t}\right)$ & $-1.465^{* * *}(0.000)$ & $-1.982^{* *}(0.030)$ & $-1.500^{* * *}(0.008)$ \\
\hline In $\left(D i s_{i}\right)$ & $-3.114^{* * *}(0.000)$ & 1 & $-2.751^{* *}(0.016)$ \\
\hline $\operatorname{In}\left(E F_{j t}\right)$ & $0.137 \quad(0.935)$ & $-1.223(0.684)$ & $-1.842(0.447)$ \\
\hline In (EDjt) & $1.030^{* * *}(0.000)$ & $0.099(0.725)$ & $0.445^{*}(0.065)$ \\
\hline In $\left(P D_{j t}\right)$ & $-0.421^{*}(0.094)$ & $-0.391 \quad(0.207)$ & $-0.235 \quad(0.374)$ \\
\hline In $\left(\right.$ Lang $\left._{j}\right)$ & $-0.990^{* *}(0.043)$ & l & $-0.871 \quad(0.305)$ \\
\hline Bord $_{j}$ & $-0.883 \quad(0.194)$ & l & $-0.301 \quad(0.814)$ \\
\hline Land $_{j}$ & $1.728^{* * *}(0.003)$ & / & $1.503(0.283)$ \\
\hline$W T O_{j}$ & $-0.870^{* *}(0.038)$ & $0.639(0.353)$ & $-0.012 \quad(0.983)$ \\
\hline$C I S_{j}$ & $0.510(0.406)$ & $-1.173(0.259)$ & $-0.388 \quad(0.639)$ \\
\hline$E E U_{j}$ & $-2.346^{* * *}(0.003)$ & $-1.881^{* *}(0.012)$ & $-1.863^{* * *}(0.008)$ \\
\hline Cons & $24.765^{* * *}(0.008)$ & $127.295(0.175)$ & $39.982^{* *}(0.020)$ \\
\hline $\mathrm{R}^{2}$ & 0.457 & 0.092 & 0.595 \\
\hline Samples & 231 & 231 & 231 \\
\hline regression groups & 21 & 21 & 21 \\
\hline F test /Wald chi2(13) & 14.070 & 2.26 & 39.430 \\
\hline Prob $>$ F/chi2 & 0.000 & 0.019 & 0.000 \\
\hline
\end{tabular}

Note: ${ }^{*} \mathrm{P}<0.1,{ }^{* *} \mathrm{P}<0.05,{ }^{* * *} \mathrm{P}<0.01$.

\& SHUZHU, 2002) classification standard for trade potential, the trade potential is divided into three types: "potential for reinvention" ( $\left.\mathrm{TP}_{\mathrm{t}} \geq 1.2\right)$; "developable potential" $\left(0.8<\mathrm{TP}_{\mathrm{t}}<1.2\right)$; "huge potential" $\left(\mathrm{TP}_{\mathrm{t}} \leq 0.8\right)$.

As can be seen from figure 3 . In 2018, the value of the trade potential index between Kazakhstan and 21 major grain trading partners had crossed the threshold value of 0.8 , but all of them were less than 1.2 , belonging to the type of "developable potential". It indicated that Kazakhstan had great potential for grain export, but it hadn't been fully exploited, and there was still a great space for trade expansion in the future. For countries whose trade potential index value was close to 1.2 , they have tended to the type of "potential for reinvention", such as Afghanistan, Azerbaijan, China, Georgia, Iran, Italy, etc. Kazakhstan should optimize the structure and types of grain products in bilateral trade, and increase its trade quantity and quality when Kazakhstan conducted grain trade with these countries. For Mongolia, the
United Arab Emirates, Turkmenistan, and Moldova, the trade potential index value had just crossed the threshold of 0.8 , which was considered as the type of "potential development". Such countries still have great development potential, and in bilateral trade between Kazakhstan and them, the existing trade barriers or obstacles should be further removed to create a more open trade environment.

In terms of the spatial pattern of grain trade potential (Figure 7), countries that had greater trade potential with Kazakhstan were mainly concentrated along the "Silk Road Economic Belt", including Sweden, Italy, Ukraine, Central Asia, China, Russia, and so on. In terms of the spatial pattern and changing trends of the grain trade potential (Figure 7), the countries mainly included China, Afghanistan, Russia, the Netherlands, Kyrgyzstan, and Sweden has an "upward" trend in grain trade potential with Kazakhstan. It indicated that the scale of Kazakhstan's grain trade with these countries had gradually 


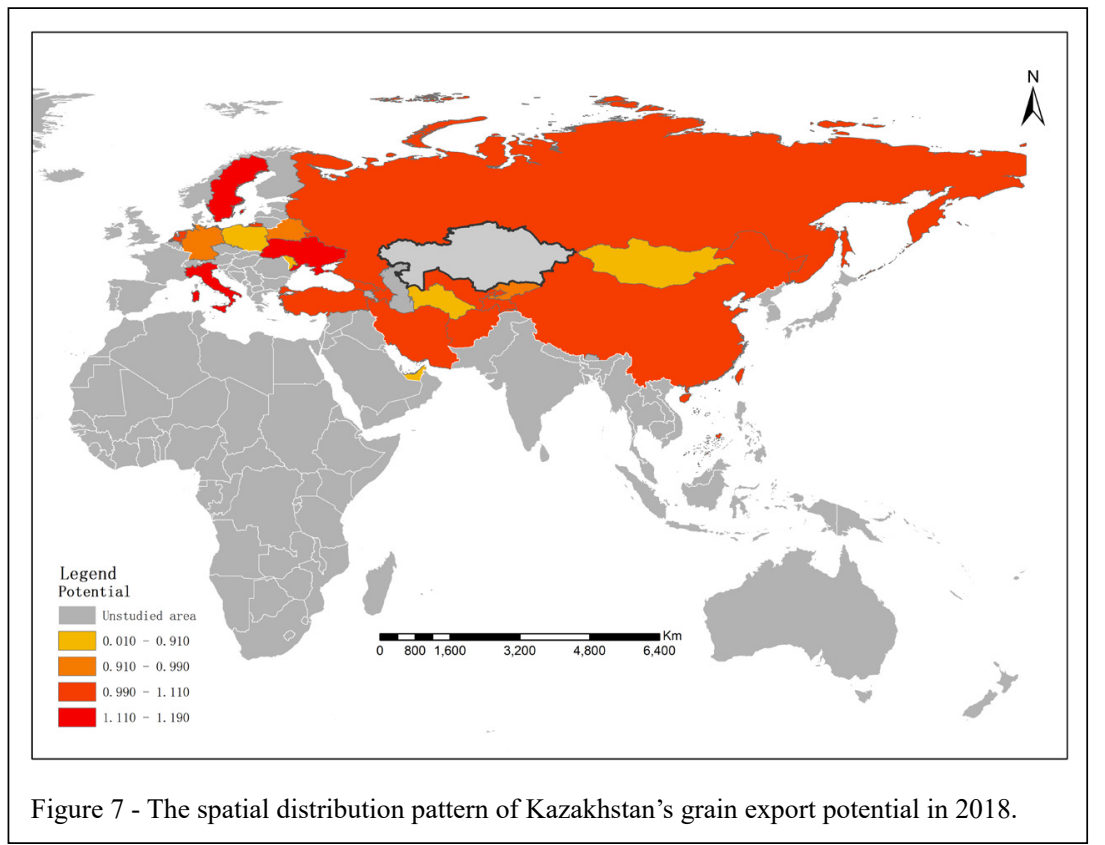

increased in recent years, but the growth potential would be gradually reduced in the future. Mongolia, Tajikistan, Ukraine, Uzbekistan, Iran, and Italy were the main countries showing a "steady" trend in grain trade potential with Kazakhstan. It indicated that the grain trade between Kazakhstan and these countries was in a stable state, and the grain export potential would not fluctuate sharply in the future. The main countries showing a "downward" trend in grain trade potential with Kazakhstan were the United Arab Emirates, Azerbaijan, Belarus, Poland, Germany, Georgia, Moldova, Turkey, and Turkmenistan. It indicated that the grain trade between Kazakhstan and these countries had gradually shrunk in recent years, and the future grain export potential had great space for improvement.

\section{Model test}

Unit root test

Panel data has the dual characteristics of time series data and section data. It is necessary to test the stability of the panel data before building the panel data regression model in order to avoid a false regression and ensure the validity of the estimated result (DEJONG et al., 1992). According to the results of Breintung, IPS, and ADF tests, all the variables reject the null hypothesis that "statistical variables have unit roots" at the level of $10 \%$.
Therefore, these sequences have no unit roots, they are first-order single integer sequences (Table 4).

\section{Co-integration test}

Since all the variables are first-order integral sequence, there may be some long-term stable co-integration relationships among these indicators. Panel co-integration test methods are mainly divided into the following two categories: one is the panel co-integration test method based on the unit root test of co-integration regression test residuals, such as the Pedroni and Kao test; and other is the Johansen trace test method. In this study, the Kao test is used to determine whether there are co-integration relationships among variables. Kao and Chiang proposed a method to test panel co-integration based on DF and ADF tests, using the residuals of static panel regression to construct statistics (KAO, 2000). If the null hypothesis that "there are no co-integration relationships among variable sequences" is rejected at the significance level of $1 \%$, it indicates that there are long-term stable equilibrium relationships among variables (Table 5).

\section{Robustness test}

In order to test the endogenous problems caused by the correlation between omission variables and explanatory variables in the process of model design test, this paper introduced the one-period 
Table 4 - Unit root test.

\begin{tabular}{|c|c|c|c|c|c|c|}
\hline \multirow[t]{3}{*}{ Variable } & \multicolumn{2}{|c|}{---------Same unit root test--------- } & \multicolumn{4}{|c|}{ 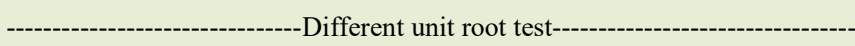 } \\
\hline & \multicolumn{2}{|c|}{------------Breintung test------------ } & \multicolumn{2}{|c|}{--------------IPS test------------- } & \multicolumn{2}{|c|}{--------------ADF-Fisher test------------- } \\
\hline & Statistics & $\mathrm{P}$-value & Statistics & $\mathrm{P}$-value & Statistics & $\mathrm{P}$-value \\
\hline$Y_{i j t}$ & -2.3917 & $0.0084^{* * *}$ & -2.4355 & $0.0074^{* * *}$ & 14.6472 & $0.0000^{* * *}$ \\
\hline$G D P_{i t} G D P_{j t}$ & -2.1862 & $0.0144^{*}$ & -1.8114 & $0.0350^{* *}$ & 4.1623 & $0.0000^{* * *}$ \\
\hline$P O P_{i t} P O P_{j t}$ & -6.8656 & $0.0000^{* * *}$ & -1.6669 & $0.0478^{* *}$ & 8.8383 & $0.0000^{* * *}$ \\
\hline$G_{p c g_{i j t}}$ & -3.3569 & $0.0004^{* * *}$ & -1.4711 & $0.0706^{*}$ & 3.8464 & $0.0001^{* * *}$ \\
\hline$E F_{j t}$ & -1.8125 & $0.0350^{* *}$ & -1.6527 & $0.0492^{* *}$ & 4.9310 & $0.0000^{* * *}$ \\
\hline$E D_{j t}$ & -1.3698 & $0.0854^{*}$ & -3.8681 & $0.0001^{* * *}$ & 10.4670 & $0.0000^{* * *}$ \\
\hline$P D_{j t}$ & -3.7548 & $0.0001^{* * *}$ & -1.4780 & $0.0697^{*}$ & 6.9747 & $0.0000^{* * *}$ \\
\hline
\end{tabular}

Note: ${ }^{*} \mathrm{P}<0.1,{ }^{* *} \mathrm{P}<0.05,{ }^{* * *} \mathrm{P}<0.01$.

lagging GDP as an instrumental variable to carry out 2SLS robustness analysis on the model (KUTTNER, 2011). This instrumental variable was highly correlated with the actual economic level of the current period, but cannot affect the economic level of the previous period. In the first stage, the dependent variable was the actual economic level, and the independent variables were instrumental variables and other control variables. The $\mathrm{p}$-value of the regression result is 0.000 , indicating that the instrumental variables were positively correlated with the actual economic level significantly. The second stage regression results showed that the regression parameter values changed after controlling the endogenous problems. For example, the regression coefficient of the WTO accession changed, and the regression parameters of the gap in GDP per capita and the real economic level decreased in significance among trading parties. The gap in GDP per capita passed the 5\% test level, and the actual economic level is no longer significant on both sides of the international trade with Kazakhstan. The relationship between the other explanatory variables and the explained variables was consistent with the results of the significance test, indicating that the argument obtained by the random-effects model remained valid, under the 2 SLS regression for controlling endogenous problems (Table 6).

\section{DISCUSSION}

This paper analyzed the spatial and temporal pattern of Kazakhstan's grain export trade and the level of international competitiveness, and uses the extended gravity model to measure its grain export potential. The main conclusions included the following:

(1) Kazakhstan's grain export trade presents a regionally concentrated geographical pattern of "Central Asia dominated, radiating all around". Uzbekistan, Tajikistan, China and Iran occupy the position of important trading partners in Kazakhstan's grain exports.(2) Kazakhstan had a low share of the international grain market, an unbalanced export structure, and limited international competitiveness.

Table 5 - Panel Cointegration Test.

\begin{tabular}{llll}
\hline Hypothetical test & Statistics & T value & P-value \\
\hline H0: No cointegration relationship & Augmented Dickey-Fuller test & -9.1550 & $0.0000^{* * *}$
\end{tabular}

Note: ${ }^{*} \mathrm{P}<0.1,{ }^{* *} \mathrm{P}<0.05,{ }^{* * *} \mathrm{P}<0.01$.

Ciência Rural, v.52, n.1, 2022. 
Table 6 - Robustness test.

\begin{tabular}{|c|c|c|}
\hline Variable & Actual economic level (first stage) & Food export trade volume (second stage) \\
\hline In $\left(G D P_{i t} G D P_{j t}\right)$ & - & $0.727(0.192)$ \\
\hline In $\left(G D P_{i t-l} G D P_{j t}\right.$ & $0.991^{* * *}(0.000)$ & - \\
\hline In $\left(P O P_{i t} P O P_{j t}\right)$ & $0.008(0.366)$ & $-0.731(0.277)$ \\
\hline In $\left(G p c g_{i j t}\right)$ & $-0.108(0.210)$ & $-1.356^{* *}(0.027)$ \\
\hline In $\left(D i s_{i}\right)$ & $-0.001(0.949)$ & $-2.392^{* *}(0.037)$ \\
\hline $\operatorname{In}\left(E F_{j t}\right)$ & $0.069^{*}(0.065)$ & $-1.339(0.582)$ \\
\hline In $\left(E D_{j t}\right)$ & $0.012^{* *}(0.016)$ & $0.461^{*}(0.055)$ \\
\hline In $\left(P D_{j t}\right)$ & $-0.009(0.109)$ & $-0.234(0.377)$ \\
\hline In $\left(\right.$ Lang $\left._{j}\right)$ & $-0.004(0.681)$ & $-0.709(0.405)$ \\
\hline Bord $_{j}$ & $0.010(0.524)$ & $-0.021 \quad(0.987)$ \\
\hline Land $_{j}$ & $0.029^{* *}(0.025)$ & $1.479(0.289)$ \\
\hline$W T O_{j}$ & $0.001(0.872)$ & $0.050(0.929)$ \\
\hline$C I S_{j}$ & $-0.149(0.273)$ & $-0.449(0.588)$ \\
\hline$E E U_{j}$ & $-0.037^{* *}(0.034)$ & $-1.850^{* * *}(0.009)$ \\
\hline Cons & $0.078(0.703)$ & $37.999^{* *}(0.027)$ \\
\hline$R^{2}$ & 0.999 & 0.594 \\
\hline Number of samples & 231 & 231 \\
\hline Number of regression groups & 21 & 21 \\
\hline F test /Wald chi2(13) & 38469.39 & 37.99 \\
\hline Prob $>$ F/chi2 & 0.0000 & 0.0003 \\
\hline
\end{tabular}

Note: ${ }^{*} \mathrm{P}<0.1,{ }^{* *} \mathrm{P}<0.05,{ }^{* * *} \mathrm{P}<0.01$.

However, wheat, barley, and buckwheat had strong export advantages; moreover, wheat, barley, oats, and millet had obvious advantages in international trade, from the perspective of subdivided grain crop varieties. (3) In terms of influencing factors, the level of economic development and economic distance had significantly promoted the scale of Kazakhstan's grain exports. While geographical distance, the difference in GDP per capita, and the fact whether trading partner countries had joined the Eurasian Economic Union, have caused significant obstacles to Kazakhstan's grain exports. In addition, common borders, language similarity, political distance, and other factors didn't have a significant impact on Kazakhstan's food exports. (4) Kazakhstan's grain export potential is "potential development type" to 21 trading partner countries, among which the export potential to 6 countries including Russia, Kyrgyzstan, and China shows an "upward" trend; to 6 countries including Tajikistan and Ukraine shows a "stable" trend, and to 9 countries including Poland and Germany shows a "declining" trend.

Based on the analysis of the above results, the author provided the discussion for Kazakhstan grain trade cooperation. (1) Kazakhstan should make use of comparative advantages to optimize the structure of grain trade in bilateral trade. Conversely, Kazakhstan should increase the exports of grain varieties with a strong competitive advantage in Kazakhstan, such as wheat, barley, and buckwheat. On the other hand, Kazakhstan should receive foreign technological investments in grain crops without the international competitiveness, such as maize, rice, and rye. More research and development on production technologies could help Kazakhstan improve its food production efficiency, for instance, enriching seed cultivation, promoting the technology for disease and pest control, as well as improving the agricultural irrigation system. (2) Investment in the construction of international transportation, logistics infrastructure, and information network infrastructure 
should be increased. Kazakhstan's government and enterprises should seize the opportunities for bilateral cooperation under the "Belt and Road" initiative and Kazakhstan's "Bright Road" new economic policy to build an all-round and multi-level interconnection network. The grain circulation efficiency, which is negatively affected by geographical distance, can be improved by actively developing the grain logistics system through investment projects. (3) Mutual benefit and win-win development can be achieved by accelerating the integration of cross-bordersubregional agriculture. Kazakhstan should take the initiative to carry out agricultural integration cooperation with China, Russia, Ukraine, Kyrgyzstan, Tajikistan, and other countries that have great potential in grain trade. This is conducive to promoting the integration of the regional agricultural factor circulation system, under the demand of regional agricultural integration and specialized division in Central Asia and Eastern Europe. In addition, reducing tariffs and non-tariff barriers can reduce trade costs and create a convenient environment for promoting regional food trade.

\section{ACKNOWLEDGEMENTS}

This research was funded by the National Natural Science Foundation of China, grant number 71673222 and 72064009, Humanities and Social Science Fund of Ministry of Education of China, grant number 15XJA790005, China Scholarship Council Funded Project, grant number 202106300001.

\section{DECLARATION OF CONFLICT OF} INTEREST

The authors declare no conflict of interest.

\section{AUTHORS' CONTRIBUTIONS}

Yameng Wang and Feng Wei designed the overall framework and did formal analysis. Peipei Huang performed statistical analyses of experimental data. Yameng Wang prepared the draft of the manuscript. Zaid Ashiq Khan completed the proofreading of the article. All authors critically revised the manuscript and approved of the final version.

\section{REFERENCES}

AIGNER, D, et al. Formulation and estimation of stochastic frontier production function models. Journal of Econometrics, v.6, n.1, p.21-37, 1977. Available from: <https://doi.org/10. 1016/03044076(77)90052-5>. Accessed: Dec. 15, 2020. doi: 10.1016/03044076(77)90052-5.

BAYDILDINA, A, et al. Agricultural policy reforms and food security in Kazakhstan and Turkmenistan. Food Policy, v.25, n.6, p.733-747, 2000. Available from: <https://doi.org/doi. org/10.1016/S0306-9192(00)00035-X>. Accessed: Dec. 15, 2020. doi: $10.1016 / \mathrm{S} 0306-9192(00) 00035-\mathrm{X}$.
CAO, S., et al. Export competitiveness of Agri-Products Between China and Central Asian Countries: A Comparative Analysis. Canadian Social Science, v.7, n.5, p.48-54,2011. Available from: $<$ https://doi.org/10.3968/j.css.1923669620110705.015>. Accessed: Nov. 10, 2020. doi: 10.3968/j.css.1923669620110705.015.

ZAVALIN, A.A., et al. Fertilizer nitrogen use. by Spring Triticale and Spring Wheat on Dark-Chestnut Soil of the Dry Steppe Zone of Kazakhstan. Russian Agricultural Sciences, v.44, n.2, p.153-156, 2018. Available from: <https://doi.org/10.3103/ S1068367418020209>. Accessed: Oct. 30, 2020. doi: 10.3103/ S1068367418020209.

DEJONG, D N, et al. The power problems of unit root test in time series with autoregressive errors. Journal of Econometrics, v.53, n.1-3,p. 323-343, 1992. Available from: <https://doi.or g/10.1016/0304-4076(92)90090-E > . Accessed: Jan. 15, 2021. doi: 10.1016/0304-4076(92)900 90-E.

GRAFE, C., et al. Beyond borders-Reconsidering regional trade in Central Asia. Journal of Comparative Economics, v.36, p.453-466, 2008. Available from: <https://doi.org/10.1016/ j.j ce.2008.03.004>. Accessed: Nov. 10, 2020. doi: 10.1016/j. jce.2008.03.004.

KAO, M. C. On the Estimation and inference of a Cointegrated Regression in Panel Data[J]. Chihwa Kao, v.15, n.1, p.109-141, 2000. Available from: $<$ https://doi.org/10.1016/ S0731-90 53(00)15007-8>. Accessed: Jan. 15, 2021. doi:10.1016/S07319053(00)15007-8.

KHAN, Y., et al. Kazakhstan: Transport and Logistical Risks in Grain Export. SSRN Electr-onic Journal. 2017. Available from: $<$ https://doi.org/10.2139/ssrn.2989522>. Accessed: Oct. 20, 2020. doi: 10.2139/ssrn.2989522.

KUTTNER, K. Monetary policy and Asset Price Volatility: Should We Refill the Bernanke-Gertler Prescription?.Department of Economics Working Papers, 2011.Available from: <https://web.williams.edu/ Economics/wp/KuttnerMonetaryPolicyAndAssetPriceVolatility. pdf>. Accessed: Jan. 15, 2021.

LING WANG. An Analysis of trade Structure,Comparative Advantage and Complementarity of Agricultural Products between China and the Main East Asian Countries.Asian Agricultu- -ral Research, v.7, n.5, p.14-20+24, 2015. Available from: <https:// doi.org/ CNKI:SUN:AAG R.0.2015-05-004>. Accessed: Dec. 10, 2020. doi: CNKI:SUN:AAGR.0.2015-05-004.

PAVLOVA, V. N., et al. Modelling the effects of climate variability on spring wheat productivity in the steppe zone of Russia and Kazakhstan. Ecological Modelling, v.277, p.57-67, 2014. Available from: $<$ https://doi.org/10.1016/j.ecolmodel.2014.01.014>. Accessed: Oct. 30, 2020. doi:10.1016/j.ecolmodel.2014.01.014.

QIANG, W., et al. Agricultural trade and virtual land use: The case of China's crop trade. Land Use Policy, v.33, p.141-150, 2013. Available from: <https://doi.org/10.1016/j. landusepol.2012.12.017>. Accessed: Oct. 20, 2020. doi: 10.1016/j. landusepol.2012.12.017.

QINGFENG, L, SHUZHU, J. China's bilateral trade arrangements from the model of trade gravity. Zhejiang Social Sciences, n.6, p.16-19, 2002. Available from: <https://doi.org/10.14167/j. zjss.2002.06.004>. Accessed: Jan. 15, 2021. doi: 10.14167/j. zjss.2002.06.004 
RABALLAND, G. A, ANDRESY. Why should trade between Central Asia and China continue to expand?. Asia Europe Journal, v.5, n.2, p. 235-252, 2007. Available from: <http://doi. org/10.1007/s10308-007-0115-5>. Accessed: Nov. 10, 2020. doi: $10.1007 / \mathrm{s} 10308-007-011$ 5-5.

SWINNEN, J., VAN HERCK, K. Food security and the transition region. Open Access Publications from Katholieke Universiteit Leuven. 2011. Available from: $<$ https://www.ebrd.com/downloads/ research/essay/foodsecurity.pdf $>$. Accessed: Oct. 20, 2020.

XIN, W., et al. Temporal and Spatial Dynamics Analysis of Grassland Ecosystem Pressure in Kazakhstan. Journal of Resources and Ecology, v.10, p.667, 2019. Available from: <https://doi. org/10.5814/j.issn.1674-764x.2019.06.012>. Accessed: Oct. 30, 2020. doi: 10.5814/j.issn.1 674-764x.2019.06.012.

ZHU, Z.. Chin utilize the Wheat Market of Russia, Ukraine and Kazakhstan:Export Potential and Barriers. Issues in Agricultural Economy, v.35, n.4, p.42-50, 2014. Available from: $<$ https://doi. org/10.13246/j.cnki.iae.2014.04.007>. Accessed: Oct. 30, 2020. doi: 10.1324 6/j.cnki.iae.2014.04.007.

ZHANAKOVA, M., et al. Modern State and Forecast of Food Production in Kazakhstan. Indian Journal of Science and Technology, v.8, n.S10, 2015.b. Available from: <https://doi. org/10.17485/ijst/2015/v8is(10)/85412>. Accessed: Jan. 15, 2021. doi: $10.17485 / \mathrm{ijst} / 2015 / \mathrm{v} 8 \mathrm{is}(10) / 85412$. 